\title{
KEDUDUKAN PERJANJIAN DALAM KITAB UNDANG-UNDANG HUKUM PERDATA DALAM SENGKETA KONSUMEN
}

\author{
Sri Istiawati \\ Universitas Amir Hamzah \\ sriistiawati1962@gmail.com
}

\begin{abstract}
Abstrak
Penelitian ini bertujuan untuk mengetahui kedudukan perjanjian dalam penyelesaian sengketa konsumen menurut Kitab Undang-Undang Hukum Perdata dan juga untuk memahami implementasi undang-undang tersebut di masyarakat. Adapun teknik yang digunakan dalam pengumpulan data melalui penelitian normatif, kemudian hasil data tersebut dianalisis menggunakan metode penelitian kepustakaan, kemudian hasil data tersebut dianalisis menggunakan metode kepustakaan dari berbagai buku, sumber bacaan, perundang-undangan. Selanjutnya dianalisis secara kualitatif. Kesimpulan yang dihasilkan bahwa ditinjau dari aspek yuridis Kitab Undang-undang Hukum Perdata telah memberikan perlindungan hukum terhadap perjanjian konsumen di ranah sengketa konsumen, akan tetapi jika dilihat dari sisi implementasi peraturan tersebut, tujuan dari perlindungan konsumen menurut Kitab Undangundang Hukum Perdata belum terlaksana dengan cukup baik sehingga masyarakat pada umumnya juga belum terlalu memahami kewajiban pelaku usaha untuk memberikan hak konsumen yang telah tercantum dalam peraturan perundang-undangan tersebut.
\end{abstract}

Kata Kunci : Perjanjian, Sengketa Konsumen, Kitab Undang-Undang Hukum Perdata.

\section{PENDAHULUAN}

Peningkatan perekonomian masyarakat sangat dibutuhkan, sehingga dilaksanakan berbagai program yang mampu meningkatkan taraf hidup bagi masyarakat. Salah satu program-nya tersebut adalah penyaluran kredit kepada masyarakat umum melalui kredit perbankan, sehingga dapat memperkuat dalam hal permodalan dan dapat juga meningkatkan taraf hidup masyarakat.

Perlindungan hukum merupakan suatu hal yang melindungi subyek-subyek hukum melalui peraturan perundang-undangan yang berlaku dan dipaksakan pelaksanaannya dengan suatu sanksi. Perlindungan hukum dapat dibedakan menjadi dua, yaitu: 
1. Perlindungan hukum preventif Perlindungan yang diberikan oleh Pemerintah dengan tujuan untuk mencegah sebelum terjadinya pelanggaran. Hal ini terdapat dalam peraturan perundang-undangan dengan maksud untuk mencegah suatu pelanggaran serta memberikan rambu-rambu atau batasan-batasan dalam melakukan suatu kewajiban.

2. Perlindungan hukum represif Perlindungan hukum represif merupakan perlindungan akhir berupa sanksi seperti denda, penjara, dan hukuman tambahan yang diberikan apabila sudah terjadi sengketa atau telah dilakukan suatu pelanggaran.( Wildan Areza, “ https://kantorhukumss.com)

Kegiatan pinjam meminjam uang secara langsung berdasarkan perjanjian baik tertulis dan tidak tertulis merupakan praktik yang telah berlangsung di tengah masyarakat. Pinjam meminjam secara langsung banyak diminati oleh pihak yang membutuhkan dana cepat atau pihak yang karena sesuatu hal tidak dapat diberikan pendanaan oleh industri jasa keuangan konvensional seperti perbankan, pasar modal atau perusahaan pembiayaan.

\section{LITERATURE REVIEW}

Kredit merupakan penyediaan uang ataupun tagihan-tagihan yang dapat disamakan dengan itu berdasarkan persetujuan pinjam meminjam antara bank dengan pihak lain dalam hal mana pihak meminjam melunasi hutangnya setelah jangka waktu tertentu dengan jumlah bunga yang telah ditetapkan.( Santosa Sarimbing, 2000:51)

Perjanjian kredit adalah perjanjian secara khusus baik oleh bank selaku kreditur maupun nasabah selaku debitur, maksudnya perjanjian kredit merupakan perjanjian obligatoir. J. Satrio membedakan perjanjian dalam arti luas dan sempit. Perjanjian dalam arti luas, suatu perjanjian berarti setiap perjanjian yang menimbulkan akibat hukum sebagai yang dikehendaki (atau dianggap dikehendaki) oleh para pihak, termasuk di dalamnya perkawinan, perjanjian kawin. Perjanjian dalam arti sempit, perjanjian hanya ditujukan kepada hubungan-hubungan hukum dalam lapangan hubungan harta kekayaan saja sebagaimana diatur dalam Buku III KUHPerdata (Satrio, 2005:27.)

Lambannya perkembangan perlindungan konsumen di negara berkembang khususnya Indonesia yang perindustriannya baru pada tahap permulaan dikarenakan oleh sikap pemerintah masih melindungi kepentingan industri yang merupakan faktor yang esensial dalam perkembangan hukum suatu negara. (Ahmad Miru, 2013 )

Berkaitan dengan hal tersebut di atas, maka perlu upaya peningkatan perekonomian masyarakat, sehingga dilaksanakannya program-program yang dapat meningkatkan taraf hidup masyarakat. Salah satu program tersebut yaitu penyaluran kredit kepada masyarakat melalui 
kredit perbankan, sehingga dapat memperkuat permodalan dan dapat meningkatkan taraf hidup masyarakat pada umumnya.

Perjanjian antara seseorang dengan orang lain ini dalam hal perjanjian pinjam meminjam, sesuai Pasal 1 ayat (1) angka 11 Undang-Undang Nomor 10 Tahun 1998 tentang Perubahan Atas Undang-Undang Nomor 7 Tahun 1992 tentang Perbankan, di dalam Undang-Undang Nomor 10 Tahun 1998 tersebut dijelaskan apa itu kredit.

Kredit yaitu penyediaan uang atau tagihan yang dapat dipersamakan dengan itu, berdasarkan persetujuan atau kesepakatan pinjam meminjam antara kreditur dengan pihak lain yang mewajibkan pihak debitur utangnya setelah jangka waktu tertentu dengan pemberian bunga. Prinsip-prinsip dalam pemberian suatu fasilitas kredit yaitu adanya kepercayaan, kesepakatan, jangka waktu, risiko, dan balas jasa. (Hermansyah, 2005)

Hubungan antara kreditur dengan debitur dalam praktik, pada umumnya bank telah membuat formulir tersendiri. Formulir tersebut telah tertera segala persyaratan-persyaratan yang harus ditentukan oleh bank. Inilah yang oleh para ahli hukum disebut sebagai perjanjian baku, artinya perjanjian yang isinya telah dilakukan dan dituangkan dalam bentuk formulir. Jika dilihat dan sudut pandang ini, jelas bagi debitur hanya ada dua pilihan yakni apakah setuju atau tidak terhadap persyaratan yang telah dibentuk oleh kreditur. Oleh karena itu muncul berbagai pendapat, bahwa perjanjian baku bertentangan dengan Pasal 1320 jo Pasal 1338 (1) (KUHPerdata maupun kesusilaan. Akan tetapi dalam praktek perjanjian ini tumbuh karena keadaan menghendakinya dan harus diterima sebagai kenyataan. (Subekti, 2005)

Perkreditan salah satu kegiatan kreditur dengan cara memberikan kredit kepada masyarakat yang mengajukan permohonan kredit. Pihak kreditur menyediakan dana bagi masyarakat yang membutuhkannya. Kredit yang diberikan dibagi dalam berbagai jenis sesuai dengan keinginan para debitur. Sebelum kredit tersebut layak diberikan atau tidak, pihak kreditur akan melakukan penilaian terhadap calon debitur agar kreditur terhindar dari kerugian akibat tidak dapat dikembalikannya kredit yang disalurkan kreditur dengan berbagai alasan. (Kasmir, 2014 )

Perjanjian menjadi instrument untuk mengakomodir atau mempertemukan kepentingan yang berbeda antara 2 (dua) pihak atau lebih, melalui perjanjian, perbedaan tersebut diakomodasi dan selanjutnya dibingkai dengan perangkat hukum, sehingga mengikat para pihak. Perjanjian bisnis pertanyaan mengenai sisi kepastian dan keadilan justru akan tercapai apabila perbedaan yang ada diantara para pihak terakomodasi melalui mekanisme hubungan kontraktual yang bekerja secara proposional.

Pasal 1320 ayat (1) Kitab Undang-undang Hukum Perdata (KUHPerdata) menentukan bahwa perjanjian atau kotrak tidak sah apabila dibuat tanpa adanya konsensus atau sepakat dari para pihak yang membuatnya. Ketentuan tersebut memberikan petunjuk bahwa hukum perjanjian dikuasai oleh "asas konsensualisme". Ketentuan Pasal 1320 ayat (1) KUHPerdata tersebut mengandung pengertian bahwa kebebasan suatu pihak untuk menentukan isi perjanjian dibatasi oleh sepakat pihak lainya. Dengan kata lain asas kebebasan berkontrak dibatasi asas konsensualisme. (Sutan Remy Sjahdeini, 2009) 
Pasal 1320 KUHPerdata merupakan instrumen pokok untuk menguji keabsahan kontrak yang dibuat para pihak. Kebebasan berkontrak dalam Pasal 1338 ayat (1) KUHPerdata mengatakan bahwa semua perjanjian yang dibuat secara sah berlaku sebagai undang-undang bagi mereka yang membuatnya. Kemudian ayat (3) mengatakan bahwa suatu perjanjian harus dilaksanakan dengan itikad baik. Pasal tersebut mengajarkan kepada kita adanya asas kebebasan berkontrak, asas pacta sund servanda, asas kepastian hukum, dan asas itikad baik atau in good faith. (Suharnoko, 2004)

\section{RESEARCH QUESTIONS}

\section{Rumusan Masalah.}

Rumusan masalah pada penelitian ini adalah :

Bagaimana kedudukan perjanjian dalam sengketa konsumen di dalam Kitab Undang-Undang Hukum Perdata terhadap Perjanjian Kredit?

Bagaimana implementasi Kitab Undang-Undang Hukum perdata terhadap Perjanjian Kredit di tengah masyarakat?

\section{Tujuan Penelitian.}

Tujuan yang ingin dicapai dari penelitian ini adalah :

a. Untuk mengetahui kedudukan dalam penyertaan perjanjian kredit dalam sengketa konsumen di dalam Kitab Undang-Undang Hukum Perdata.

b. Untuk memahami implemetasi Kitab Undang-Undang Hukum Perdata di tengah-tengah masyarakat.

\section{METHOD}

Pendekatan penelitian yang dipergunakan pada penelitian ini adalah pendekatan per-undangundangan (statute approach). Pendekatan ini dilakukan dengan menelaah undang-undang dan regulasi yang bersangkutpaut dengan permasalahan yang sedang diteliti (Peter Mahmud Marzuki, 2007 : 93).

Sumber bahan hukum pada penelitian ini terdiri atas bahan hukum primer yaitu bahan hukum yang berupa peraturan perundang-undangan (Jhoni Ibrahim, 2006 : 295), dan bahan hukum sekunder yang berupa buku-buku hukum termasuk skripsi, tesis, disertasi hukum, jurnal-jurnal hukum, kamus-kamus hukum dan komentar-komentar atas putusan pengadilan yang berkaitan dengan permasalahan penelitian (Peter Mahmud Marzuki, 2014 : 195-196).

Untuk mengumpulkan bahan hukum yang diperlukan dalam penelitian ini digunakan tehnik penelitian kepustakaan (library research). Alat yang dipakai untuk mengumpulkan bahan- 
bahan hukum adalah strudi dokumen. Analisa bahan hukum pada penelitian ini dilakukan dengan menggunakan metode kualitatif (Suharsini Arikunto, 1996 : 293).

\section{DISCUSSION}

\section{Kedudukan Dalam Penyertaan Perjanjian Kredit Dalam Sengketa Konsumen Di Dalam Kitab Undang-Undang Hukum Perdata.}

Ketentuan Pasal 1338 KUHPerdata menjadi pedoman dan dasar hukum bagi kekuatan yang mengikat perjanjian tersebut. Menurut Pasal 1338 memuat, setiap perjanjian yang dibuat secara sah berlaku sebagai undang-undang bagi para pembuatnya. Dengan kata lain jika perjanjian itu telah dibuat secara sah, memenuhi syaratsyarat sahnya perjanjian sebagaimana disebut dalam Pasal 1320, maka kedudukan dan/atau keberlakuan perjanjian bagi para pihak dapat disamakan dengan sebuah undang-undang yang mempunyai kekuatan mengikat dan memaksa. Tentu saja pengikat itu hanya menyangkut dan sebatas pada hal-hal pokok yang termuat dalam perjanjian.

Seperti yang kita ketahui bahwa perjanjian itu sendiri mempunyai 4 syarat yang harus dipenuhi, menurut ketentuan Kitab Undang-Undang Hukum Perdata:

1. Adanya persetujuan kehendak antara pihak-pihak yang membuat perjanjian (consensus)

2. Ada kecakapan pihak-pihak untuk membuat perjanjian (capacity)

3. Ada suatu hal tertentu (object)

4. Ada suatu sebab yang halal (legal cause)

Pengertian Perjanjian dimuat dalam Bab II Buku III Kitab UndangUndang Hukum Perdata tentang "Perikatan-Perikatan yang Dilahirkan Dari Kontrak atau Perjanjian", Sesuai dengan bunyi Pasal 1233 KUHPerdata: "Perikatan lahir karena suatu persetujuan atau karena undangundang. Perikatan ditujukan untuk memberikan sesuatu, untuk berbuat sesuatu, atau untuk tidak berbuat sesuatu", kemudian mulai Pasal 1313 sampai dengan Pasal 1351 mengatur tentang perjanjian, dimana ketentuan dalam Pasal 1313 merumuskan pengertian perjanjian yang berbunyi : "Suatu perjanjian adalah suatu perbuatan dengan mana satu orang atau lebih mengikatkan dirinya terhadap satu orang lain atau lebih.

Didalam hukum keperdataan terdapat dua macam perjanjian yaitu perjanjian dibawah tangan dan perjanjian notaril, antara perjanjian di bawah tangan dan perjanjian yang dibuat dengan akta notariil terdapat perbedaan dalam hal kekuatan pembuktiannya. Perbedaan kekuatan pembuktian perjanjian kredit secara di bawah tangan dengan perjanjian kredit dalam bentuk akta notariil diterangkan sebagai berikut

1. Perjanjian Bawah Tangan

a. Jika salah satu pihak menyangkal tanda tangannya, maka pihak lain yang harus membuktikan bahwa tanda tangan yang disangkal itu adalah benar adanya. 
b. Salah satu pihak dapat mengajukan alibi bahwa tanda tangan tersebut benar tanda tangannya tetapi pengisiannya diluar pengetahuannya, sehingga di pengadilan perjanjian kredit di ba wah tangan tersebut hanya dipakai sebagai permulaan bukti saja, bukan merupakan alat bukti yang sempurna.

\section{Perjanjian Notarial}

a. Jika salah satu pihak menyangkal tanda tangannya maka pihak tersebut yang harus membuktikan bahwa tanda tangannya adalah tidak benar atau palsu.

b. Jika salinan otentiknya hilang, maka bisa dimintakan lagi kepada notaris yang bersangkutan. Bahkan apabila minutnya (akta asli) hilang, maka salinan otentiknya mempunyai kekuatan yang sama dengan minutnya. Membuktikan kebenaran formal, dianggap benar bahwa para pihak menerangkan apa yang ditulis dalam akta tersebut dan material. (Abdulkadir Muhammad, 2010)

Perjanjian sesuai isi Pasal 1338 KUHPerdata yang berbunyi : "Semua persetujuan yang dibuat sesuai dengan undang-undang berlaku sebagai Undang-undang bagi mereka yang membuatnya. Persetujuan itu tidak dapat ditarik kembali selain dengan kesepakatan kedua belah pihak, atau karena alasan-alasan yang ditentukan oleh Undang-undang. Persetujuan harus dilaksanakan dengan itikad baik".

Perjanjian menjadi instrument yang dapat mengakomodir dan mempertemukan kepentingan yang berbeda antara 2 (dua) pihak atau lebih, melalui perjanjian, perbedaan tersebut diakomodasi dan selanjutnya dibingkai dengan perangkat hukum, sehingga dapat memberikan efek mengikat bari para pihak. Perjanjian bisnis pertanyaan mengenai sisi kepastian dan keadilan justru akan tercapai apabila perbedaan yang ada diantara para pihak terakomodasi melalui mekanisme hubungan kontraktual yang bekerja proposional.

Pengertian kredit dalam Pasal 1 angka 11 UU Perbankan dapat diketahui unsur-unsur kredit diantaranya adalah unsur kepercayaan. Oleh sebab itu dengan adanya pemberian kredit berarti adanya pemberian kepercayaan, namun demikian jika ditelaah lebih lanjut ternyata unsur yang lainnya yakni:

a. Kesepakatan Pihak-pihak yaitu kesepakatan antara si pemberi kredit dan si penerima kredit. Hal mana kesepakatan tersebut dituangkan dalam suatu perjanjian dimana masing-masing pihak menyetujui hak dan kewajiban dalam perjanjian tersebut.

b. Jangka Waktu Dalam pemberian kredit telah disepakati tentang kapan seorang debitur harus mengembalikan pinjamannya, dapat berbentuk jangka pendek, menengah maupun jangka panjang.

c. Resiko Adanya tenggang waktu pengembalian yang telah di tentukan akan menimbulkan suatu resiko, hal ini harus di sadari bahwa masa depan tidak dapat di pastikan, oleh karena itu pihak bank selaku pemberi pinjaman sudah harus memperhitungkan resiko yang akan dihadapi, seperti resiko kredit, resiko infestasi, likuiditas, operasional, penyelewengan serta resiko fiducia. 
d. Balas Jasa. Yaitu merupakan keuntungan atas pemberian kredit oleh bank sebagai balas jasa dalam bentuk bunga dan administrasi kredit ini merupakan keuntungan bank konvensional, sedangkan bank dengan prinsi syariah keuntungan nya berupa bagi hasil

e. Pertukaran Nilai Bahwa kredit tanpa perhutungan dalam bentuk pertukaran nilai ekonomi tidak dapat di sebut transaksi, sebab jika tidak ada unsur pertukaran nilai ekonomi berarti tidak terdapat kesinambungan nilai sehingga ada pihak yang di rugikan.

Berdasarkan perjanjian ini perjanjian kredit dapat diartikan merupakan perjanjian pinjam meminjam antara Bank sebagai kreditur dengan pihak lain sebagai debitur yang mewajibkan debitur untuk melunasi utangnya setelah jangka waktu tertentu dengan pemberian bunga.

Akibat perjanjian yang telah memenuhi syarat-syarat sahnya perjanjian disebutkan dalam Pasal 1338 KUHPerdata yang menyebutkan:

1. Semua persetujuan yang dibuat secara sah berlaku sebagai undang-undang bagi mereka yang membuatnya.

2. Persetujuan-persetujuan itu tidak dapat ditarik kembali selain dengan sepakat kedua belah pihak atau karena alasan-alasan yang oleh undang undang dinyatakan cukup untuk itu.

3. Persetujuan-persetujuan hanya berlaku antara pihak-pihak yang membuatnya. Perjanjian yang dibuat secara sah yaitu memenuhi syarat-syarat Pasal 1320 KUHPerdata berlaku sebagai Undang-Undang bagi para pihak yang membuat perjanjian. Artinya pihak-pihak harus mentaati isi perjanjian seperti mereka mentaati Undang-Undang sehingga melanggar perjanjian yang mereka buat dianggap sama dengan melanggar undang-undang. Perjanjian yang dibuat secara sah mengikat pihakpihak dan perjanjian tersebut tidak boleh ditarik kembali atau membatalkan harus memperoleh persetujuan pihak lainnya.

\section{Implementasi Kitab Undang-Undang Hukum Perdata Terhadap Perjanjian}

Pada dasarnya suatu perjanjian atau kontrak berasal dari suatu perbedaan atau ketidaksamaan kepentingan diantara para pihak dan perumusan hubungan kontraktual tersebut pada umumnya diawali dengan proses negosiasi diatara para pihak tersebut. Sehingga dengan kontrak perbedaan tersebut diakomodir dan selanjutnya dibingaki dengan perangkat hukum sehingga mengikat bagi para pihak. (Agus Yudha Herdoko, 2019)

Adapun pendapat-pendapat para ahli mengenai perjanjian adalah sebagai berikut,:

Menurut R. Subekti Perjanjian adalah suatu peristiwa hukum dimana seseorang berjanji kepada orang lain atau dimana dua orang itu saling berjanji untuk melaksanakan suatu hal2. 
Menurut R Wirjono Projodikoro Perjanjian adalah suatu hubungan hukum mengenai harta benda antara dua pihak dimana satu pihak berjanji untuk melakukan suatu hal atau tidak melakukan suatu hal janji sedangkan pihak lain menuntut pelaksanaannya .

Dalam pembuatan suatu perjanjian atau kontrak para pihak diharuskan memperhatikan beberapa prinsip yang sangat mendasar dalam pembuatan kontrak tersebut. Adapun prinsipprinsip tersebut adalah memahami akan syarat-syarat sahnya suatu perjanjian atau kontrak dan asas-asas serta unsur-unsur dalam suatu perjanjian atau kontrak.

Berbicara tentang sifat perjanjian kredit ada berbagai pendapat dari para sarjana yang mengaitkannya dengan ketentuan pasal 1754 BW (KUHPerdata) yakni :

"Perjanjian pinjam meminjam mengganti adalah persetujuan dengan mana pihak yang satu meberikan kepada pihak yang lain suatu jumlah ketentuan barang-barang menghabis karena pemakaian. Dengan syarat bahwa pihak yang belakangan ini akan mengembalikan jumlah yang sama dan macam-macam keadaan yang sama pula”.

Dalam pelaksanaan suatu perjanjian atau kontrak membawa konsekuensi bahwa seluruh harta kekayaan seseorang atau badan yang diakui sebagai badan hukum, akan dipertaruhkan dan dijadikan jaminan atas setipa perikatan atau kontrak orang perorangan dan atau badan hukum tersebut, sebagaimana yang dijelaskan dalam Pasal 1131 KUHPerdata. (Gunawan Widjaja. 2003)

Kitab Undang-Undang Hukum Perdata senantiasa mengatur hubungan hukum antara kedua belah pihak. Agar perjanjian yang dibuat tersebut sesuai dengan kebutuhannya, dan senantiasa dapat dijadikan sebagai pedoman sesuai dengan aturan hukum yang berlaku.

\section{CONCLUSIONS}

Dilihat dari aspek yuridis Kitab Undang-Undang Hukum Perdata dari sudur pandang perjanjian, Keudukan Perjanjian sangat diperlukan dalam sengketa konsumen dalam hal memberikan perlindungan dan payung hukum.

Jika ditinjau dari sisi implementasinya Kitab Undang-Undang Hukum Perdata Pasal 1313 yang memuat syarat-syarat sudah mengatur secara sedemikian rupa, namun pada pelaksanaannya masyarakat belum terlalu mengerti kedudukan perjanjian dalam hal sengketa konsumen.

\section{REFERENCES}

[1] Santosa Sarimbing. 2020. Hukum Perbankan. Mandar Maju, Bandung.

[2] Satrio, 2005, Hukum Perikatan, Perikatan Yang Lahir Dari Perjanjian, Buku I Citra Aditya Bakti. Bandung

[3] Miru, Ahmad, 2013. Prinsip-Prinsip Perlindungan Hukum Bagi Konsumen Di Indonesia, Cetakanke-2. RajaGrafindo Persada. Jakarta. 
[4] Hermansyah, 2005. Hukum Perbankan Nasional Indonesia. Kencana. Jakarta.

[5] Subekti, 2005. Hukum Perjanjian. Intermasa. Jakarta.

[6] Kasmir, 2014, Dasar-Dasar Perbankan.. RajaGrafindo Persada. Jakarta.

[7] Sjahdeini, Sutan Remy. 2009. Kebebasan Berkontrak, Pustaka Utama Grafiti. Jakarta.

[8] Suharnoko, 2004. Hukum Perjanjian. Kencana. Jakarta.

[9] Abdulkadir Muhammad. 2010. Hukum Dan Lembaga Keuangan, Alumni, Bandung [10] Agus Yudha Herdoko. 2019. Hukum Perjanjian. Prenada Media.

[11] Gunawan Widjaja dan Kartini Muljadi, 2003. Perikatan yang Lahir dari UndangUndang, PT. RajaGrafindo Persada, Jakarta. 